104 THE STUDY OF THE SENSOR BLOCK DURING LABOR ANALGESIA: PROGRAMMED INTERMITTENT EPIDURAL BOLUSES (PIEB) VERSUS CONTINUOUS EPIDURAL INFUSION (CEI)

${ }^{1}$ E Upryamova*, ${ }^{2}$ E Shifman, ${ }^{2} \mathrm{~A}$ Ovezov. ${ }^{1}$ Moscow Regional Scientific Research Institute of Obstetrics and Gynecology, Moscow, Russian Federation; ${ }^{2}$ Moscow Regional Research and Clinical Institute (MONIKI), Moscow, Russian Federation

10.1136/rapm-2021-ESRA.104

Background and Aims Randomized trials show that the use of the PIEB reduce the frequency of the motor block, fewer manual boluses and provides greater maternal satisfaction compared to CEI.

The aim of study was to compare the dynamics of the sensory block of PIEB+PCEA to CEI+PCEA for maintenance labor analgesia.

Methods We studied 70 subjects. The level of the sensor block evaluated the «pin-prick» test. All parturients divided into 2 groups:

4 - loading dose of levobupivacaine $0.125 \%$ - $10.0 \mathrm{ml}$, then CEI $(0.0625 \%-15 \mathrm{ml} /$ hour $)+$ PCEA $(0.0625 \%-10.0$ $\mathrm{ml}$ every $\left.20^{\prime}\right)$;

5 - loading dose of levobupivacaine $0.125 \%$ - $10.0 \mathrm{ml}$, then PIEB $\left(0.0625 \%\right.$ - $9.0 \mathrm{ml}$ every $\left.45{ }^{\prime}\right)+$ PCEA $(0.0625 \%$ - $10.0 \mathrm{ml}$ every 10').

Results The results indicate that in the PIEB group, the level of sensory block in patients was higher after 15 minutes the start of analgesia and remained so until the end of the observation period (median PIEB Th5 versus Th8 in the CEI group, ( $p<0,0004)$. When cervical dilation full (II stage), the intervals and distributions of the sensor block level in the CEI and PIEB groups completely diverge $(p<0.00001)$. The median and peak frequency of the sensor block level in the CEI group are at Th9, while the same statistics in the PIEB group are Th6.

Conclusions PIEB + PCEA technique maintained a consistently high level of sensor block throughout the study compared to PCEA + CEI, which ensured effective analgesia in the first and second stages of labor.

\section{QUESTIONNAIRE SURVEY OF SATISFACTION WITH LABOUR NEURAXIAL ANALGESIA}

S Carvalho, A Carrão, I Ferraz* , C Castanheira, M Ghira. Hospital Beatriz Ângelo, Loures, Portugal

10.1136/rapm-2021-ESRA. 105

Background and Aims Neuraxial analgesia for labour has become common practice in developed countries. The aim of this study was to evaluate the degree of satisfaction with neuraxial analgesia during labour in our institution which is requested by more than $80 \%$ of women.

Methods We conducted a retrospective questionnaire survey to women up to 3 days after delivery, between July and September 2020. The primary outcome was the degree of satisfaction (using a numeric rating scale from 0 to 10 ). Secondary outcomes were pain relief (using a numeric rating scale from 0 to 10), side effects and reasons not to use neuraxial analgesia. Statistical analysis was performed using SPSS $^{\circledR}$ software (version 22).

Results A total of 232 women answered the questionnaire, of which $47.4 \%$ had a combined spinal-epidural technique,
44.4\% epidural, $0.4 \%$ spinal and $7.8 \%$ did not have neuraxial analgesia. The median degree of satisfaction was $10[9 ; 10]$. Pain after the technique reduced from a median of $9[7 ; 10]$ to $0[0 ; 2]$. Side effects and other complaints are shown in figure 1. Main reasons not to use neuraxial analgesia were neuraxial analgesia not being offered due to complete dilation on admission $(66.7 \%)$, tolerance to labour pain $(16.7 \%)$ and previous unsatisfactory labour neuraxial analgesia (5.6\%). About

BEATRIZ

ÂNGELO

Exma. Sanhora

Dra. Sofia Almeida Carvalho

Médica Interna de Fcrmaçăo Especfica no Sarviço de Anestesiologia do Hospital Beatriz Ângelo

Loures, 26 de fevereire de 202

\begin{abstract}
N:Ref. ${ }^{2}$ 3568/2021_MJHE-mal/NO
Estudo HBA n.'0550

Correio étrónico \& PMP

Assunto: Inquérito de satisfaçáo da analgesia epidural de trabalho de parto

Eymá. Sénhora Dr a Soria Almeida Cavalho,

No seguimento da submissão a este Hospital do estudo melhor identificado em epigrafa no qual $V$. Exa partidipa na qualidade de Investigador Principal, temos o prazer de iniormar que a Comissáo de Etica para a Saúde (CES) do HBA considera asseguradas as questóes éticas reləcionadas com a realizaçăo do estudo, peo que deliberou a sua aprovação em reuniăo extraorcinária do dia 26 de fevereiro do corrente ano.
\end{abstract}

Com os rossos melhores cumprimentos.

A Presidente da Comissắo de Ética para a Saúde do HBA

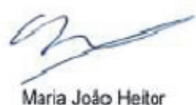

Abstract 105 Figure 1

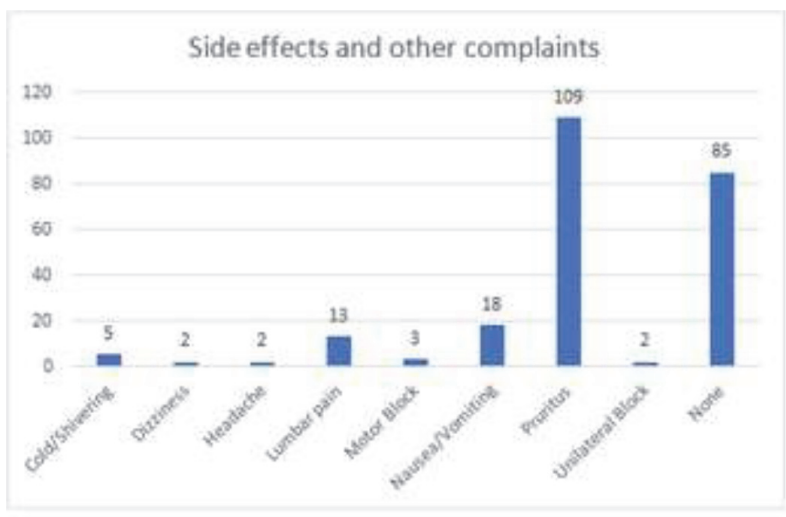

Abstract 105 Figure 2 
$2.3 \%$ would not request neuraxial analgesia in a next pregnancy.

Conclusions In our sample, there was a high adherence to neuraxial analgesia (92.2\%), with an even distribution between epidural and combined spinal-epidural techniques. Even with minor side effects, mainly pruritus, most women were satisfied and $97.7 \%$ would request neuraxial analgesia again.

\section{TIME TO EXPAND THE DIAGNOSTIC AND INTERVENTIONAL USES OF ULTRASOUND IN OBSTETRIC ANAESTHESIA - INTRODUCING A HOLISTIC COURSE AT A LONDON TERTIARY OBSTETRIC HOSPITAL}

Y Mandour*, M Khaku, H Caulfield, I Dick. University College London Hospitals NHS Foundation Trust, London, UK

\subsection{6/rapm-2021-ESRA.106}

Background and Aims Ultrasound use is expanding our anaesthetic practice in obstetrics for both diagnostic and interventional purposes. These include scans for central neuraxial blockade, truncal blockade and finally focussed point-of-care ultrasound scans (POCUS). We aimed to design and deliver a practical course to enhance knowledge and skills in these areas.

\section{Abstract 106 Table 1 Course contents}

\begin{tabular}{|c|c|}
\hline Lectures & Workshops \\
\hline \multicolumn{2}{|c|}{ US guided Central Neuraxial blockade } \\
\hline \multicolumn{2}{|c|}{ Truncal blocks - US guided TAP \& QL blocks } \\
\hline \multicolumn{2}{|c|}{ POCUS - Cardiac } \\
\hline \multicolumn{2}{|c|}{ POCUS - Airway \& lungs } \\
\hline \multicolumn{2}{|c|}{$\begin{array}{l}\text { Focussed Assessment with sonography for } \\
\text { trauma (FAST) scanning }\end{array}$} \\
\hline $\begin{array}{l}\text { Anticoagulants in } \\
\text { regional anaesthesia }\end{array}$ & \\
\hline $\begin{array}{l}\text { Updates/ Complications } \\
\text { of regional anaesthesia }\end{array}$ & \\
\hline
\end{tabular}

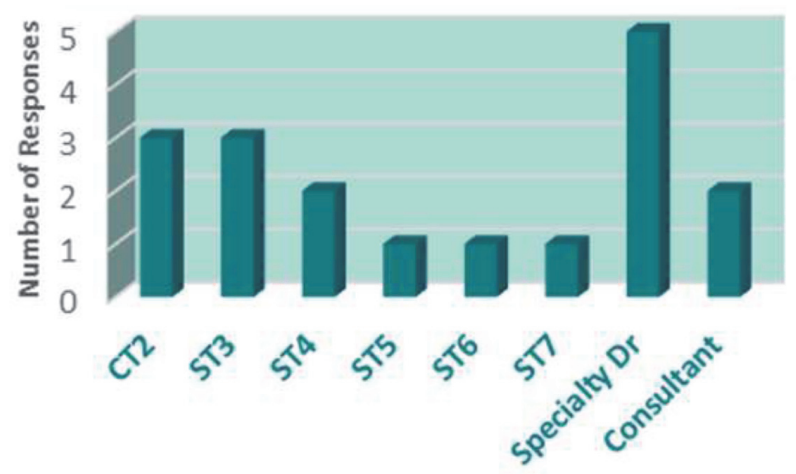

Training Grade

Abstract 106 Figure 1 Training grades of course candidates

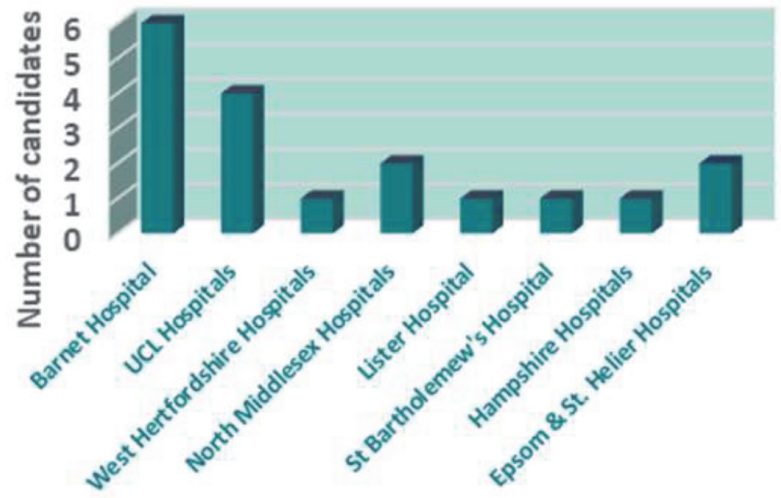

Abstract 106 Figure 2 Hospitals of course candidates

Methods Our course consisted of a series of lectures and corresponding small-group workshops which covered the topics in table 1.

The course included candidates of all training grades in the UK (figure 1).

Candidates represented eight large NHS Trusts in South East England (figure 2).

Results We achieved a $100 \%$ response rate to our post-course evaluation survey (18/18). All attendees gave global positive feedback about our multi-dimensional educational tool for the use of this technology in obstetric anaesthesia. The majority of candidates expressed more interest in workshops and hands-on training.

Conclusions Ultrasound technology is enriching obstetric anaesthesia with diagnostic and interventional techniques which are invaluable for parturients with multiple comorbidities or trauma victims. National anaesthetic training programme in the UK training modules for obstetric anaesthesia should strive to recognise the use of ultrasound as an integral part of this complex subspecialty.

\section{COMPARING ULTRASOUND TO BODY MASS INDEX FOR MEASUREMENT OF DURAL DEPTH}

T Al-Ani*. Glasgow Royal Infirmary, Glasgow, UK

\subsection{6/rapm-2021-ESRA.107}

Background and Aims Measuring the distance from the skin to posterior dura (SPD) before lumbar epidural placement may prevent accidental dural puncture. ${ }^{1}$ This study compares the accuracy of measurement of SPD using ultrasound versus body mass index (BMI) in obstetric patients.

Methods An anonymous retrospective data of pre-procedural ultrasound and intraprocedural Tuohy needle measurements of SPD were collected from anaesthetic charts of thirty parturient with varying gestational stages, maternal age and ethnicity, all had received lumbar epidurals for labour analgesia using 18G Tuohy needle and loss of resistance to saline. Then, using the documented patient's BMI the SPD was calculated using the general regression equation $(\mathrm{Y}=2.52+0.11 \mathrm{BMI}){ }^{2}$ The accuracy of measurement of SPD for the two groups: Ultrasound SPD versus BMI SPD compared to the Touhy needle SPD was analysed using Wilcoxon signed-rank test. Ethics approval is not required as per NHS Greater Glasgow and Clyde policy. 